談 話 室

第 3 回産研国際シンポジウム

松本卓也

大阪大学産業科学研究所

䜳 567-0047 大阪府茨木市美穂ヶ丘 8-1

(2000 年 7 月 18 日受理)

\section{Third International Sanken Symposium}

Takuya MATSUMOTO

The Institute of Scientific and Industrial Research, Osaka University

8-1 Mihogaoka, Ibaraki, Osaka 567-0047

(Received July 18, 2000)

第 3 回産研国際シンポジウムが 3 月 14 日 (火) と 15 日 (水) の 2 日間, 大阪大学吹田キャンパスの銀杏会館 にて開催された。大阪大学産業科学研究所は総合理工学 研究所であるので, 研究分野は, 材料・デバイス, 情報・ 知能, 生体・医薬を中心に多岐にわたる。これらの分野 を網羅したシンポジウムを短い会期で開催することは無 理なので, 毎年, 複数の研究分野から参加可能な広がり のあるテーマを設定して本シンポジウムは開催されてい る。今年はナナノレクトロニクスの最前線〜デバイス， マテリアル，コンピューティング」“ Advanced Nanoelectronics: Devices, Materials, Computing” のテーマで開催さ れた。会議の参加者数は 277 人で, 22 件の招待講演 (国 外 13 件) とポスター発表 132 件 (国外 12 件) が行われ た。参加者数は予想を超え, 会期がわずか 2 日間の研究 所主催のシンポジウムとしては，盛況であった。

ナノェレクトロニクスが含む研究分野は極めて幅広 い。本シンポジウムでは, 単一原子操作を用いた極限的 科学・技術に関する話題から，分子エレクトロニクスや 量子コンピューティングのように, まだ萌芽的なアイデ ア先行の分野まで, バランスよく取り上げられるととも に，現在ホットな話題となっている物質系にも焦点を絞 り，全部で 8 つセッションが用意された。

第 1 日目は開会の挨拶のあと“ Nanoscience and Devices”のセッションで3 件の講演が行われた。まずは じめに, IBM (Almaden) の Eiglerにより, 近藤効果で 生じた量子蜃気楼をSTM で観測した研究が紹介され た。この量子傆気楼は, 会議の前に一般の新聞紙上など
でも報道されたこともあり，朝一番にもかかわらず多く の聴衆を集めた。このあと，阪大の河田による近接場走 査光学顕微鏡を用いたナノスケール領域における振動分 光に関する講演, NTT の高橋によるシリコン微細構造 を用いた単一電子デバイスに関する講演が行われた。午 前の2つ目のセッションは“ Computational Physics”と 題して，計算物理を用いたナノスケール構造体の電子物 性に関する講演が行われた。米国 NREL の Zungerによ る半導体量子ドットの理論計算，阪大の吉田による透明 磁性体の材料設計, 韓国 KAIST の Chang によるカーボ ンナノチューブの変形と電気伝導に関する計算結果が報 告された。

昼食とポスターセッションの後, 午後は現在高い関心 を集めている物質に焦点を合わせたセッションとして， “ GaN-related Materials and Devices”が行われた。フラン ス CRHEA/CNRS の MassiesによるMBE を用いたナノ スケール構造の作製と評価，阪大の朝日によるガスソー ス MBEを用いた新規半導体の作製, ドイツ Otto-vonGuericke 大学の Christen による GaN ヘテロ構造の光学 的キャラクタリゼーションに関する講演があつた。GaN は実用デバイスとして注目されており，具体的かつ熱心 な質疑応答が行われた。

午後の後半のセッションは“Molecular Devices“ であつ た。米国 UCLA の Heath から, 分子ェレクトロニクス に基づいた論理演算回路構築に関する講演があつた。光 の後, 東北大の原田による光学活性分子を用いた光分子 モーターに関する講演, 九大の筒井による有機エレクト ロルミネッセンス (EL) 素子の現状と将来に関する講 演が行われた。EL 素子の話以外は, まだ実用には程遠 い内容ではあるが, 夢を感じさせるセッションであった。

第 2 日目の午前には, 物質に焦点を合わせたセッショ ンが集められた。まず “" Oxide Materials and Devices” のセッションで高温超伝導体の発見者の 1 人である IBM (Zurich) の Bednorz の講演からスタートした。Bednorz はペロブスカイト酸化物の多樣な物性に着目し, これらをうまく組み合わせることが, 新しいデバイスを 構築するための鍵であると述べた。このあと, オランダ Twente 大学の Blank が間欠的レーザー蒸着法を用いた 酸化物薄膜成長に関する精密な研究成果を報告した。午 前の第 2 番目のセッションは “ ZnO-related Materials and Devices”であった。米国 Eagle-Picher 社の Cantwell によ る Seeded CVD を用いた薄膜成長に関する講演, 東工大 の川崎による $\mathrm{ZnO}$ の新しい応用に関する刺激的な講演 が行われた。このあと ", III-V Nanostructures and Devices” 
のセッションで, 米国 UCS の Tuによる新規オプトエ レクトロニクス材料に関する研究, ドイツ Berlin 工科大 学の Ledentsov による量子ドットレーザーに関する研究 が紹介された。

第 2 日目も昼食の後に, ポスターセッションが行われ た。この後, 本シンポジウム最後のセッションとして “ Advanced Computing/Quantum Computer”が行われた。 まず, 米国空軍研究所の Pao によるコンピューティング のプロトコルと方法論における物質及びプロセス設計に 関する講演があった。続いて阪大の北川が量子計算のた めの分子系探索について, NEC の中村が, 超伝導キュ ビットにおけるコヒーレンスの問題について, 弚れぞれ 講演した。最後に米国 Maryland 大学の Kane によるシリ
コン半導体を用いた量子コンピューティングに関する講 演で締めくくられた。

以上, 紹介したように, ナノエレクトロニクスは非常 に広範な科学・技術の分野を含んでいる。研究対象とな る物質系も急速に多樣性を増しつつある。また，たとえ ば分子ェレクトロニクスと量子コンピューティングのよ うに, 従来は関連性が小さいと考えられていた分野間に も密接なつながりが生まれつつある。このような状況の 中で,一研究者がナノエレクトロニクス全体を見渡すこ とは容易ではない。本シンポジウムでは, 口頭発表は招 待講演のみであったため，1つの会場で全ての講演を通 して聞くことができた。この分野の全体像を把握できる 良い機会であった。 